\title{
Role of Natural Volatiles and Essential Oils in Extending Shelf Life and Controlling Postharvest Microorganisms of Small Fruits
}

\author{
Toktam Taghavi * (1), Chyer Kim and Alireza Rahemi \\ Agricultural Research Station, Virginia State University, Petersburg, VA 23806, USA; ckim@vsu.edu (C.K.); \\ a_rahemi@yahoo.com (A.R.) \\ * Correspondence: ttaghavi@vsu.edu
}

Received: 31 August 2018; Accepted: 3 October 2018; Published: 5 October 2018

\begin{abstract}
Small fruits are a multi-billion dollar industry in the US, and are economically important in many other countries. However, they are perishable and susceptible to physiological disorders and biological damage. Food safety and fruit quality are the major concerns of the food chain from farm to consumer, especially with increasing regulations in recent years. At present, the industry depends on pesticides and fungicides to control food spoilage organisms. However, due to consumer concerns and increasing demand for safer produce, efforts are being made to identify eco-friendly compounds that can extend the shelf life of small fruits. Most volatiles and essential oils produced by plants are safe for humans and the environment, and lots of research has been conducted to test the in vitro efficacy of single-compound volatiles or multi-compound essential oils on various microorganisms. However, there are not many reports on their in vivo (in storage) and in situ (in the field) applications. In this review, we discuss the efficacy, minimum inhibitory concentrations, and mechanisms of action of volatiles and essential oils that control microorganisms (bacteria and fungi) on small fruits such as strawberries, raspberries, blueberries, blackberries, and grapes under the three conditions.
\end{abstract}

Keywords: postharvest diseases; food borne pathogens; bacteria; fungi; food safety; plant extracts; small fruits; grape; strawberry; blueberry; raspberry; blackberry; essential oils

\section{Introduction}

There are two major concerns for the handling and consumption of small fruits. First is their short shelf life, and second is food safety. Fresh produce in particular is gaining increasing attention in the current food safety and regulatory climate. Centers for Disease Control and Prevention [1], has developed a comprehensive list of food sources of all foodborne illnesses in the United States (U.S.) and fresh produce accounted for nearly half of illnesses among all types of foods reported during 1998-2008.

Standard small fruit production practices discourage growers from washing fruits after harvest and during storage. This may contribute to the buildup of food-borne bacteria and may pose a food safety risk to consumers since small fruits are eaten fresh. Also, small fruits have a very short shelf life due to their susceptibility to spoilage pathogens, physiological disorders and mechanical injury [2]. This is partly due to their high nutrient content and water activity, and low $\mathrm{pH}$ which make them susceptible to fungal attack. Thus, losses during harvest, handling and marketing are sometimes as high as 50\% [3]. Pathogens may also produce mycotoxins that make the fruit harmful to consumers [4].

Low temperature storage is not adequate to extend fruit shelf-life for prolonged storage or for delivery to distant markets. Therefore, controlled temperature combined with high $\mathrm{CO}_{2}$ in modified atmospheres has been recommended to reduce spoilage [5]. Although small fruits can tolerate high 
$\mathrm{CO}_{2}$ levels in storage, it causes off-flavors in the long term [6], and application of fungicides is still the main method to control postharvest diseases in small fruit [6-8]. However, under optimal conditions for disease development, fungicides are not effective and growers may try to overcome this challenge by increasing fungicide applications, which in turn leads to higher residue levels in produce [7]. In the long term, the population of beneficial organisms declines as residual fungicides lead to the development of resistant fungi $[6,8,9]$. High levels of pesticide residues on berries are of particular concern because they are consumed fresh shortly after harvest. This has placed strawberries at the top of the "Dirty Dozen" list [10] and raised concerns about human health and pronounced oncogenic risk $[8,11]$. Other concerns with excessive pesticide application are increased cost, handling hazards, and threats to the environment [12]. Therefore, many restrictions are imposed on pesticide application in many countries around the world $[9,12]$.

Nowadays, consumers concerned about fungicide residues in small fruits demand safer alternatives to replace synthetic pesticides [13]. Therefore, new disease control technologies that are safe for humans and the environment are needed [12]. Biological control, such as the use of plant volatiles is an exciting alternative [8]. Plants synthesize an enormous number of volatiles (phenols or their by-products). Many of them are responsible for flavor, while some have useful medicinal compounds [12].

Natural plant products tend to have low mammalian toxicity, broad-spectrum antimicrobial activity, are less hazardous than synthetic compounds, and are generally more acceptable to the public $[4,7,12,14-16]$. At present, there are many research results on the efficacy of plant volatiles to control fungal and microbial growth in in vitro (laboratory) conditions $[17,18]$, but very few discuss their efficacy to extend the shelf life of fresh produce.

In this review, we discuss the efficacy of volatiles (single compounds) and essential oils (EOs, group of compounds) produced by plants to control food-borne bacteria (Salmonella spp., Escherichia coli, and Listeria) and fruit pathogens (mainly Botrytis and Colletotrichum) on extending the shelf life of small fruits, such as strawberries (Fragaria $\times$ ananassa Duch), raspberries (Rubus spp.), blueberries (Vaccinium spp.) and grapes (Vitis vinifera L.). We also provide insight into their in vitro, in vivo (in storage) and in situ (in the field) applications, and their mechanisms of action. A summary of the papers reviewed is presented in Table 1. 
Table 1. In vitro, in vivo (in storage), and in situ (in field) applications of volatiles (single compounds) and essential oils (EOs, multiple compounds) on diseases and plants, and parameters measured. The abbreviations are explained in the notes.

\begin{tabular}{|c|c|c|c|c|}
\hline Volatile, EO, plant extract & Concentration & Disease/plant & Parameters measured & Reference \\
\hline \multicolumn{5}{|l|}{ In vitro application } \\
\hline $\begin{array}{l}\text { (E)-hex-2-enal, hexanal, (E)-non-2-enal, nonanal, } \\
\text { 2-carene, limonene and aldehydes upon wounding } \\
\text { of tomato leaves }\end{array}$ & $\begin{array}{l}10 \% \text { solution }(w / w) \text { of the test } \\
\text { compound and diluted serially } \\
(w / w) \text { to } 1 \text { and } 0.1 \% \text { solutions. }\end{array}$ & $\begin{array}{l}\text { Altenaria alternata and Botrytis } \\
\text { cinerea }\end{array}$ & Hyphal length & Hamilton-Kemp et al. [19] \\
\hline $\begin{array}{l}\text { Aldehydes hexanal and (E)-hex-2-enal; the alcohols } \\
\text { hexan-1-ol, (Z)-hex-3-en-1-ol, and (E)-hex-2-en-1-ol; } \\
\text { and the esters (Z)-hex-3-enyl acetate, (Z)-hex-2-enyl } \\
\text { acetate, and hexyl acetate. }\end{array}$ & 33.78 to $1351.35 \mu \mathrm{L} \mathrm{L}^{-1}$ & Colletotrichum acutatum & $\begin{array}{l}\text { Mycelial growth, conidial } \\
\text { germination, development of } \\
\text { appressoria, MID, ID95, ID50 }\end{array}$ & Arroyo et al. [9] \\
\hline $\begin{array}{l}\text { Fifteen compounds from aldehydes, alcohols, } \\
\text { ketones, an ester and a mixed alcohol and ketone } \\
\text { moiety. }\end{array}$ & $0,0.02,0.04,0.1,0.4 \mu \mathrm{L} \mathrm{mL}^{-1}$ & B. cinerea & Growth of fungi, $\%$ of control & Vaughn et al. [20] \\
\hline Hexanal in $\beta$-cyclodextrin complex & $0,1,1.5,2,4,5,7,10 \mu \mathrm{L}$ & $\begin{array}{c}\text { C. acutatum, A. alternata and } B . \\
\text { cinerea }\end{array}$ & Radial growth of cultures in $\mathrm{cm}^{2}$ & Almenar et al. [14] \\
\hline Extracts from 345 plants and 49 essential oils & $\begin{array}{l}10 \% \text { plant extract solution, } 50 \\
25,12.5,6.25,3.13,1.56,0.78 \\
\text { and } 0.39 \% \text { EOs }\end{array}$ & B. cinerea & Reduction in spore germination & Wilson et al. [18] \\
\hline $\begin{array}{l}\text { Twenty six essential oils of ten plants (Chenopodium } \\
\text { ambrosioides, Eucalyptus citriodora, Eupatorium } \\
\text { cannabinum, Lawsonia inermis, Ocimum canum, O. } \\
\text { gratissimum, O. sanctum, Prunus persica, Zingiber } \\
\text { cassumunar and Zingiber officinale) }\end{array}$ & $\begin{array}{c}500 \mathrm{ppm} \text {, different for MIC and } \\
\text { MFC }\end{array}$ & $\begin{array}{l}\text { B. cinerea, and only three } \\
\text { selected essential oils on } 15 \\
\text { other fruit rotting pathogens }\end{array}$ & $\%$ mycelial inhibition, MIC & Tripathi et al. [4] \\
\hline $\begin{array}{l}\text { Oregano, thyme, dictamnus, marjoram (carvacrol), } \\
\text { lavender (linalool, linalyl acetate), rosemary, sage } \\
\text { (eucalyptol) and pennyroyal (cis-menthone) EOs }\end{array}$ & Not specified & $\begin{array}{l}\text { B. cinerea, Fusarium sp., } \\
\text { Clavibacter michiganensis }\end{array}$ & Radial growth on PDA & Daferera et al. [7] \\
\hline EOs of two clonal types of Thymus vulgaris & $50,100,200 \mathrm{ppm}$ & B. cinerea and Rhizopus stolonifer & $\%$ inhibition of radial growth & Bhaskara Redy et al. [6] \\
\hline Lemongrass (Cympopogon citratus) & $25,50,100,500 \mathrm{ppm}$ & $\begin{array}{l}\text { B. cinerea, Colletotrichum coccodes, } \\
\text { C. herbarum, R. stolonifer, } \\
\text { Aspergillus niger }\end{array}$ & $\begin{array}{l}\text { Pathogen development, spore } \\
\text { production, spore germination, } \\
\text { germ tube length }\end{array}$ & $\begin{array}{c}\text { Tzortzakis \& Economakis } \\
\text { [13] }\end{array}$ \\
\hline Eighteen EOs & $50-3000 \mu \mathrm{LL}^{-1}$ & $\begin{array}{c}5 \text { pathogens from } 5 \text { crops } \\
\text { including B. cinerea from grape }\end{array}$ & $\begin{array}{l}\text { Visual inspection, inhibition of } \\
\text { mycelial growth (\%) }\end{array}$ & Combrinck et al. [21] \\
\hline $\begin{array}{l}\text { Thyme (P-cymene, thymol, } \alpha \text {-terpineol, carvacrol, } \\
\text { Cinnamon bark (cinnameldehyde, cinnamyl acetate), } \\
\text { Clove bud (eugenol, } \beta \text {-caryophyllene) }\end{array}$ & $\begin{array}{l}13 \text { concentrations from } 0.067 \text { to } \\
\quad 667 \mu \mathrm{L} \mathrm{L}^{-1} \text { of media }\end{array}$ & C. acutatum & $\begin{array}{l}\text { Mycelial growth, conidial } \\
\text { germination, appressoria } \\
\text { formation }\end{array}$ & Duduk et al. [2] \\
\hline
\end{tabular}


Table 1. Cont.

\begin{tabular}{|c|c|c|c|c|}
\hline Volatile, EO, plant extract & Concentration & Disease/plant & Parameters measured & Reference \\
\hline \multicolumn{5}{|l|}{ In vitro application } \\
\hline Origanum vulgare $\mathrm{L}$. essential oil & $\begin{array}{l}40,20,10,5,2.5,1.25 \\
\quad 0.06 \mu \mathrm{LL}^{-1}\end{array}$ & R. stolonifer and A. niger & $\begin{array}{l}\text { Mycelial growth of the test fungi, } \\
\text { spore germination and } \\
\text { morphological changes }\end{array}$ & Santos et al. [22] \\
\hline Essential oils of seven Moroccan Labiatae & $\begin{array}{c}0,10,50,100,150,200 \text { and } \\
250 \mathrm{ppm}\end{array}$ & B. cinerea & $\begin{array}{l}\text { Percentage of inhibition of radial } \\
\text { growth vs control }\end{array}$ & Bouchra et al. [23] \\
\hline \multicolumn{5}{|l|}{ In vivo (in storage) application } \\
\hline (E)-hex-2-enal & $4,5,10,20$, and $50 \mu \mathrm{L} \mathrm{L}^{-1}$ & $\begin{array}{l}\text { C. acutatum inoculated } \\
\text { strawberry fruit }\end{array}$ & $\begin{array}{l}\text { Incidence of infected fruits, scale } \\
0,1\end{array}$ & Arroyo et al. [9] \\
\hline $\begin{array}{l}\text { Three groups of naturally occurring volatile } \\
\text { compoundscontains } 24 \text { volatiles }\end{array}$ & $2,10,100 \mu \mathrm{L} / 250 \mathrm{~mL}$ bottle & Strawberry, blackberry \& grape & $\begin{array}{l}\text { Lesion appearance and size, } \\
\text { phytotoxicity }\end{array}$ & Archbold et al. [24] \\
\hline $\begin{array}{l}\text { Fifteen volatiles released by red raspberries and } \\
\text { strawberries }\end{array}$ & $0.4 \mu \mathrm{L} \mathrm{mL}^{-1}$ & $\begin{array}{l}\text { B. cinerea on raspberry and } \\
\text { strawberry }\end{array}$ & $\begin{array}{l}\text { Rated for development of fungi } \\
\text { and damage of volatile }\end{array}$ & Vaughn et al. [20] \\
\hline Thymol, menthol, eugenol & $200 \mathrm{mg} \mathrm{L}^{-1}$ & Strawberry & $\begin{array}{l}\text { Sugar, acid, anthocyanin, TPC, } \\
\text { ORAC, DPPH, HRS, SARS, } \\
\text { flavonoids }\end{array}$ & Wang et al. [16] \\
\hline $\begin{array}{l}\text { Carvacrol, anethole, cinnamaldehyde, cinnamic acid, } \\
\text { perillaldehyde, linalool, and p-cymene }\end{array}$ & $200 \mathrm{mg} \mathrm{L}^{-1}$ & Blueberries & $\begin{array}{c}\text { ORAC) and hydroxyl radical } \\
(\bullet \mathrm{OH}) \text { scavenging, total } \\
\text { anthocyanins, total phenolics } \\
\text { capacity, sugars, organic acids, } \% \\
\text { of fruit showing fungal symptoms }\end{array}$ & Wang et al. [25] \\
\hline Volatile substances emitted by 'Isabella' grapes & $\begin{array}{c}0,300,400, \text { or } 500 \mathrm{~g} \text { of 'Isabella' } \\
\text { grapes }\end{array}$ & B. cinerea in kiwifruit & $\begin{array}{l}\text { \# infected kiwifruit, \# kiwifruit on } \\
\text { which fungal fruiting bodies had } \\
\text { appeared }\end{array}$ & Kulakiotu, et al. [8] \\
\hline Eucalyptus and cinnamon EOs & $50,500 \mathrm{ppm}$ & Strawberry, tomato & $\begin{array}{l}\text { Degree of visual infection, weight } \\
\text { loss, TSS, firmness, TA, TPC, }\end{array}$ & Tzortzakis [12] \\
\hline Thyme, Cinnamon bark, Clove bud EO & 13 conc. $(0.067-667)$ & C. acutatum & $\begin{array}{l}\text { \# of diseased fruit or mycelial } \\
\text { growth }\end{array}$ & Duduk et al. [2] \\
\hline $\begin{array}{l}\text { Essential oils from thyme (T. vulgaris), clove } \\
\text { (Syzygium aromaticum), and massoialactone (bark of } \\
\text { the tree Cryptocarya massoia) }\end{array}$ & $\begin{array}{c}(0,0.033,0.1,0.33,1.0 \text { and } 3.3 \%) \\
\text { for phytotoxicity, B. cinerea } \\
\text { inoculated on heated lesions } \\
\text { and treated with }(0.033,0.1 \\
0.33 \%) \text { EOs }\end{array}$ & B. cinerea in grapes & $\begin{array}{l}\text { Scaling the formation of necrosis } \\
\text { on the underside of the leaves }\end{array}$ & Walter et al. [26] \\
\hline
\end{tabular}


Table 1. Cont.

\begin{tabular}{|c|c|c|c|c|}
\hline Volatile, EO, plant extract & Concentration & Disease/plant & Parameters measured & Reference \\
\hline \multicolumn{5}{|l|}{ In vivo (in storage) application } \\
\hline Eugenol or thymol & $\begin{array}{c}75 \text { or } 150 \mu \mathrm{L} / \mathrm{bag} \text { (vol. was not } \\
\text { mentioned) }\end{array}$ & Grape & $\begin{array}{l}\text { Ethylene, weight loss, color and } \\
\text { firmness, TSS, TA, sensory } \\
\text { analysis, decay, microorganism } \\
\text { analysis, antioxidant activity, TPC, } \\
\text { total anthocyanins, organic acids, } \\
\text { and sugar contents }\end{array}$ & Valero et al. [27] \\
\hline O. vulgare L. essential oil & $\begin{array}{c}40,20,10,5,2.5,1.25,0.06 \mu \mathrm{L} \\
\mathrm{mL}^{-1}\end{array}$ & Grapes & $\begin{array}{l}\text { TSS, TA, weight loss, color, } \\
\text { firmness, anthocyanin, and } \\
\text { sensory characteristics of the } \\
\text { fruits during storage }\end{array}$ & Santos et al. [22] \\
\hline O. sanctum, P. persica and Z. officinale & 200,100 and $100 \mathrm{ppm}$ & B. cinerea in grapes & Initiations of rotting of the fruits & Tripathi et al. [4] \\
\hline Thymus danensis and T. carmanicus & $150,300,600,1200 \mu \mathrm{L} \mathrm{L}^{-1}$ & $\begin{array}{c}\text { R. stolonifer, Penicillium } \\
\text { digitatum, A. niger and B. cinerea } \\
\text { strawberry }\end{array}$ & Disease incidence $(\%)$ & Nabigol \& Morshedi [28] \\
\hline EOs of two T. vulgaris clones & $50,100,200 \mathrm{ppm}$ & B. cinerea and R. stolonifer & Decay of fruit & Bhaskara Reddy et al. [6] \\
\hline $\begin{array}{l}\text { Carvacrol, anethole, cinnamic acid, perillaldehyde, } \\
\text { cinnamaldehyde, and linalool }\end{array}$ & $200 \mathrm{mg} \mathrm{L}^{-1}$ & Raspberries & $\begin{array}{c}\text { SOD, CAT, G-POD, AsA-POD, } \\
\text { GR, GSH-POD, MDAR, DHAR, } \\
\text { Protein content, TPC, Total } \\
\text { anthocyanins, ORAC, HOSC, } \\
\text { DPPH, flavonoids }\end{array}$ & Jin et al. [29] \\
\hline Carvacrol, cinnamaldehyde & $0.50 \%$ & $\begin{array}{l}\text { Escherichia coli and P. digitatum } \\
\text { on blueberries }\end{array}$ & $\begin{array}{l}\text { Microbial populations, fruit } \\
\text { firmness }\end{array}$ & Sun et al. [30] \\
\hline Bergamot EO, on grape & $2 \% w / v$ & Grape cv Muscatel & $\begin{array}{l}\text { Microbial counts, weight loss, } \\
\text { 'Brix, total phenols, antioxidant } \\
\text { activity, color and texture, } \\
\text { respiration rate }\end{array}$ & $\begin{array}{l}\text { Sánchez-González et al. } \\
\text { [17] }\end{array}$ \\
\hline \multicolumn{5}{|l|}{ In situ (field application) } \\
\hline Thyme R oil in two years and massoialactone year 2 & 0.033 Thyme, 0.1 massoialactone & Botrytis in grape & $\begin{array}{c}\text { B. cinerea sporulation on leaves, } \% \\
\text { of berries showing } B \text {. cinerea } \\
\text { sporulation }\end{array}$ & Walter et al. [26] \\
\hline
\end{tabular}




\section{Control of Food Born Bacteria by Volatiles and Essential Oils in Small Fruits}

Most of the studies on the application of natural volatiles and essential oils (EOs) to control foodborne pathogens, such as Salmonella Typhimurium, Salmonella enterica, E. coli, and Listeria monocytogenes, etc., have been conducted in vitro in petri dishes [31]. However, very few reports discuss the efficacy of plant volatiles and essential oils to control foodborne bacteria on small fruits during storage. Sun et al. [30] studied chitosan coating mixed with six different essential oils in vitro to control E. coli and Penicillium digitatum in blueberries during storage. Carvacrol and cinnamaldehyde had high antimicrobial capacity and were selected for in vivo studies to control blueberry pathogens.

Sánchez-González et al. [17] tested biodegradable coatings with and without bergamot essential oil (from Citrus $\times$ bergamia Risso \& Poit.) on table grapes (V. vinifera L.) during storage. They found that incorporation of bergamot essential oil improved the antimicrobial activity of the coatings and significantly reduced mold, yeast, and mesophile counts.

\section{Control of Fungal Diseases in In Vitro Conditions}

\subsection{Effect of Volatiles on Fungal Diseases in In Vitro}

Plant volatiles are mainly aldehydes, alcohols, acids and esters synthesized through the hydroperoxide lyase (HPL) and liposygenase (LOX) pathways. These products are involved in plant wounding responses and may have physiological roles (such as self-defense and antimicrobial properties) beside their role in aroma biosynthesis [9].

The effect of single compound terpene, terpenoids, and aldehyde vapors and their mixture from crushed tomato (Solanum sp. 'Mountain Pride') leaves were tested on conidiospores from Alternaria alternata and Botrytis cinerea. (E)-hex-2-enal and hexanal inhibited A. alternata hyphal growth and $B$. cinerea spore growth, while the terpene limonene and 2-carene did not affect hyphal growth [19]. However, the synergistic effect of other bioactive volatiles should not be excluded. The unsaturated aldehydes (E)-non-2-enal and (E)-hex-2-enal, were significantly more active than saturated hexanal, in inhibiting fungal growth [19].

Similarly, Arroyo et al. [9] examined the antifungal activity of eight aroma compounds of strawberry fruit against Colletotrichum acutatum in vitro. The aldehyde (E)-hex-2-enal significantly inhibited mycelial growth and spore germination (minimum inhibitory dose, MID of 33. $6 \mu \mathrm{L} \mathrm{L}^{-1}$ ). Hexanal was only effective when applied in higher doses of up to 10 times [9]. The inhibitory concentrations of hexanal on pathogens reported by others are quite different. Almenar et al. [14] observed that hexanal completely inhibited the growth of C. acutatum, B. cinerea, and A. alternata at low concentrations of 1.1, 1.3 and $2.3 \mu \mathrm{L} \mathrm{L}^{-1}$ air respectively. Andersen et al. [32] reported that $0.00007 \mu \mathrm{L}$ $\mathrm{L}^{-1}$ air of hexanal reduced A. alternata growth on agar by $50 \%$. Song et al. [33] reported that $0.5 \mu \mathrm{L} \mathrm{L}^{-1}$ air inhibited B. cinerea growth on potato dextrose agar (PDA ) media and Archbold et al. [24] showed $0.008 \mu \mathrm{L} \mathrm{L}^{-1}(2 \mu \mathrm{L} / 250 \mathrm{ml}$ container) hexanal reducing $B$. cinerea in inoculated strawberries by $90 \%$. In contrast to all these reports, Hamilton-Kemp et al. [19] observed a stimulatory effect of hexanal on A. alternata and B. cinerea mycelial growth at low levels.

In an experiment, among five antifungal volatiles (hexan-1-ol, benzaldehyde, 2-nonanone, (Z)-hex-3-en-1-ol and (E)-hex-2-enal) released by raspberry and strawberry fruits, (E)-hex-2-enal and benzaldehyde were the most effective against three fungal (A. alternata, B. cinerea, and Colletotrichum gloeosporioides) species in vitro [20].

To our knowledge, only one study reported the application of slow-release hexanal in postharvest fungal control in small fruits. To develop a controlled release mechanism, hexanal was incorporated into a polymer ( $\beta$-cyclodextrin) and then evaluated in vitro against $B$. cinerea, $C$. acutatum and $A$. alternata. Hexanal was fungistatic on all three pathogens and fungicidal on C. acutatum. C. acutatum was more responsive to hexanal than the other two pathogens. The data suggested that a slow-release compound provided a more uniform volatile dose during storage and was more effective in reducing postharvest diseases [14]. 


\subsection{Effect of Essential Oils on Fungal Diseases In Vitro}

Essential oils (EO) are naturally occurring substances extracted from plant material and are a complex of volatiles produced in different plant parts. They constitute different plant secondary metabolites mainly from terpenes, and other aromatic compounds [34]. They have various functions in plants such as resistance against pest and diseases [13]. Essential oils with active ingredients can be used as an alternative management method to control microorganisms. They have shown antibacterial, antifungal, and antioxidant properties against some important food-borne and plant pathogens.

Essential oils have three main features. Since they are produced by plants, they are safer to the environment and humans than synthetic alternatives. Second, they have low risk of resistance development by pathogens because they are a mixture of oil components and pathogens lack the mechanism to develop resistance against a range of chemicals. Third, there is a broad range of natural compounds that have the potential to be used for controlling pathogens [7]. Essential oils are generally considered safe for treating food products, and sometimes even beneficial in extending their shelf life. However, phytotoxicity, off-flavors and off-odors have also been reported.

A large number of papers have been published on the biological activity of essential oils. The large variability among the data may be attributed to factors such as genetics, climate, geographical and seasonal conditions, distillation techniques and time of harvest [4]. Consequently, the chemical composition of essential oils needs to be standardized and reproducible [7].

Most of the reports on the inhibition of post-harvest fungal pathogens by essential oils focus on in vitro conditions [28]. The efficacy of several essential oils and their antimicrobial compounds were studied in extending the shelf life and inhibiting decay of strawberries. Only a limited number of literature investigated the effect of essential oils and/or plant extracts against $B$. cinerea or other small fruit pathogens $[4,6,7,18]$.

Two studies $[4,18]$ screened a large number of essential oils and plant extracts for their efficacy against $B$. cinerea. Wilson et al. [18] screened 345 plant extracts for their antifungal activity and thirteen were highly antifungal. The extracts from Capsicum and Allium genera were the most effective and inhibited B. cinerea spore germination after 48 and 24 hours, respectively. Among 49 essential oils tested, red thyme (Thymus zygis L.), palmarosa (Cymbopogon martini (Roxb.) Will. Watson), clove buds (Syzygium aromaticum (L.) Merr. E L.M. Perry), and cinnamon leaf (Cinnamomum zeylanicum Blume) greatly inhibited germination of $B$. cinerea spores at the lowest concentration tested $(0.78 \%$ dilution; initial concentration was not provided). The essential oils with high antifungal activity and the highest frequency were: cineole, limonene, $\alpha$-pinene, $\beta$-myrcene, camphor and $\beta$-pinene [18].

Tripathi et al. [4] tested essential oils of 26 plants against B. cinerea. Among them, ten plants (Zingiber officinale Roscoe, Z. cassumunar Roxb., Prunus persica (L.) Batsch, Ocimum sanctum L., Ocimum gratissimum L., Ocimum canum Sims, Lawsonia inermis L., Eupatorium cannabinum L., Eucalyptus citriodora Hook., and Chenopodium ambrosioides L.) showed $100 \%$ toxicity at $500\left(\mathrm{mg} \mathrm{L}^{-1}\right)$. The essential oils were a mixture of nine major and sixteen minor compounds with possible synergistic effects between major and minor constituents [4].

In another study, growth of B. cinerea mycelium was completely inhibited by thyme, oregano, dictamnus and marjoram essential oils at 150, 200, 200 and $300 \mathrm{mgml}^{-1}$, respectively. The main component of oregano oil was thymol, and the main component of marjoram, thyme and dictamnus oils was carvacrol [7].

Bhaskara Reddy et al. [6] reported that, there is a significant difference between the antifungal activity of two clones of Thymus vulgaris (Laval-1 and Laval-2) against two strawberry storage pathogens (Rhizopus stolonifer and B. cinerea). Oil from Laval-2 clones showed higher antifungal activity in vitro and decay control action in vivo which is mainly due to its higher carvacrol, thymol and linalool contents. Lemongrass oil reduced germ tube length and spore germination in R. stolonifer, Colletotrichum coccodes, and B. cinerea [13]. 
Combrinck et al. [21] tested eighteen essential oils on five pathogens, including B. cinerea isolated from grapes. B. cinerea was the most susceptible to cinnamon, thyme, and eugenol at the lowest concentration tested $\left(500 \mu \mathrm{L} \mathrm{L}^{-1}\right)$.

In the study conducted by Duduk et al. [2], clove bud, thyme and cinnamon bark essential oils were fungistatic on mycelial growth of C. acutatum ( $667 \mu \mathrm{L} \mathrm{L}^{-1}$ of medium) and their volatiles disabled appressoria formation $\left(1.53 \mu \mathrm{L} \mathrm{L}^{-1}\right.$ of air) and prevented conidia germination $\left(76.5,15.3\right.$ and $1.5 \mu \mathrm{L} \mathrm{L}{ }^{-1}$ of air respectively).

Santos et al. [22] tested the efficacy of chitosan packages incorporated with Origanum vulgare L. essential oil on Aspergillus niger and R. stolonifer on grapes. Mycelial growth was inhibited by essential oil in in vitro conditions.

Bouchra et al. [23] evaluated essential oils of seven Labiatae plants grown in Morocco for their antifungal activity in in vitro conditions against B. cinerea. Thymus glandulosus Req. and Origanum compactum Benth., with thymol and carvacrol as main compounds, inhibited mycelium growth more effectively than others.

\subsection{Mechanism of Action of Volatiles and Essential Oils on Pathogen Growth in In Vitro Conditions}

Different concentrations of hexanal are effective against fungal growth. Caccioni et al. [35] believed that, the actual vapor pressure rather than the concentration of volatiles determines their effectiveness. Therefore, the effectiveness of hexanal depends on its vapor pressure (effective concentration), its initial amount and the tested fungus. In essential oils, the antifungal activity strongly depends on the proportion of the individual components [36].

Gardini et al. [37] posited that hexanal is not soluble in water and therefore in the culture medium. However, Almenar et al. [14] showed that PDA medium absorbed hexanal and prevented A. alternata and C. acutatum growth (3.0 and $3.3 \mu \mathrm{L}$ respectively). Therefore, if media can absorb henxanal, we hypothesize that fresh produce can also absorb small amounts of volatiles and extend their shelf life by extruding it.

The saturation status of volatile compounds seems to also affect their efficacy with unsaturated compounds being more reactive than saturated ones. Hamilton-Kemp et al. [19] and Andersen et al. [32] demonstrated that (E)-hex-2-enal (unsaturated aldehyde) was more effective against B. cinerea and A. alternata hyphal growth than hexanal (saturated aldehyde). Arroyo et al. [9] showed that aldehydes ((E)-hex-2-enal and hexanal) which are less saturated than alcohols and esters, are more effective in fungal inhibition. In contrast, among the alcohols tested, (E)-hex-2-en-1-ol, and (Z)-hex-3-en-1-ol which are less saturated than hexan-1-ol, showed lower antifungal activity against $C$. acutatum mycelial growth [9]. The reason could be due to a different reaction of $C$. acutatum to volatiles compared to B. cinerea and A. alternata as was mentioned by Almenar et al. [14]. Arroyo et al. [9] studied the conidial cells of $C$. acutatum treated with (E)-hex-2-enal by transmission electron microscopy. They observed that cell components were highly disorganized and cell wall and plasma membrane were disrupted, resulting in lysis of organelles and cell death.

Almenar et al. [14] reported that $B$. cinerea and A. alternata reacted to hexanal similarly but different from C. acutatum. They suggested that the inhibition mechanisms are different, but no further explanation was provided. However, Hamilton-Kemp et al. [19] reported that C. acutatum and B. cinerea responded similarly meaning hyphal growth was inhibited by aldehyde but not terpenes. However, they suggested that more cautious interpretation is needed as variable culture conditions and organism strain may affect the results.

The difference in the affinity of these compounds with microbial membranes seems to affect their effectiveness and their toxicity [14]. Cell membrane permeability and its interaction with volatiles are key elements in the effectiveness of gaseous compounds [38]. Changes in the permeability of cell membranes, and degeneration of the ion gradients adversely affect vital cell processes and lead to cell death [16]. 
In this regard, Kulakiotu et al. [8] reported cell protoplast secretion without initial cell wall disruption in mycelial hyphae of $B$. cinerea exposed to volatiles of grape (Vitis labrusca, cv. Isabella) resulting in cell wall deformation. Hyphae from the control treatment was healthy, possessing conidiophores with abundant conidia [8]. The mechanism of action of volatiles inhibiting hyphal growth and their effect on membranes needs further investigation. Thymol and carvacrol also showed antimicrobial activity against natural grape yeasts in red wines via damage to the membrane, leakage of cytoplasmic content and finally inhibition of erogosterol biosynthesis [39].

The fact that different natural compounds have a different antifungal profile suggests that different modes of action exist. In human pathogens, several mechanisms of actions have been reported for antifungal activity of natural plant compounds. Sivakumar et al. [40] reported that chalcones (aromatic ketons found in a few plant species) are able to disrupt fungal cell wall formation and cell lysis by inhibiting synthesis of the cell wall polysaccharide 1,3-beta-D-glucan. They can also interrupt cell division by inhibiting the conversion of tubulin into microtubules [41].

Aldehydes, another group of volatiles, inhibit fungal cell division by reacting with, and inactivating sulfhydryl, the functional group involved in fungal cell division. Some aldehydes (such as cinnamaldehyde, citral and perillaldehyde) are good electron acceptors and form a charge transfer complex with electron donors present in fungal cells, thus interfering with fungal metabolism [42].

Volatiles with $\alpha, \beta$-unsaturated cabonyl groups (such as enones and enals) often react with nucleophilus in fungi through the Michael reaction to create chemical modifications and interrupt fungal growth [43] of C. acutatum, Colletotrichum fragariae, C. gloeosporioides, Fusarium oxysporum, B. cinerea, and Phomopsis sp. Nevertheless, the accessibility of $\alpha, \beta$-unsaturated carbonyl groups to bulky nucleophile biomolecules plays an important role in their antifungal activity [44].

It has been reported that mitochondrial electron-transfer respiration systems in mammals were inhibited by C. ambrosioides essential oil component such as carvacrol [36]. Another component of the EO (ascaridole) formed toxic radicals in the presence of $\mathrm{Fe}^{2+}$ and reduced hemin [36]. The phenol carvacrol has shown antibacterial properties due to its ability to distribute into membranes and to permeate in them causing a breakdown of ion gradients. Carvacrol also increases the passive permeability of the cell membrane and modulates certain $\mathrm{Ca}^{2+}$ permeable transient receptor potential channels, inhibits sarcoplasmic reticulum $\mathrm{Ca}^{2+}$ ATPase, and activates ryanodine receptors in skeletal muscle, thereby influencing intracellular calcium homeostasis (Monzote et al. [36] and references therein).

\section{Control of Fungal Diseases in In Vivo (in Storage) Conditions}

\subsection{Effect of Volatiles on Fungal Diseases In Vivo}

Arroyo et al. [9] reported complete inhibition of C. acutatum development after five days by (E)-hex-2-enal in inoculated strawberry fruit. This compound also effectively reduced B. cinerea disease symptoms in grapes, blackberry (Rubus spp.) and strawberry [24]. Vaughn et al. [20], evaluated fifteen volatiles from strawberries and red raspberries during ripening and found that five compounds (hexan-1-ol, benzaldehyde, 2-nonanone, (Z)-hex-3-en-1-ol and (E)-hex-2-enal) completely inhibited $A$. alternata, B. cinerea, and C. gloeosporioides on strawberry and raspberry fruits.

In another study, treatments with thymol, eugenol, and menthol reduced decay in strawberries, with thymol being the most effective at slowing berry decay compared to the other two compounds [16]. Similarly, p-cymene, linalool, carvacrol, anethole, and perillaldehyde effectively retarded blueberry mold formation, while cinnamic acid and cinnamaldehyde were less effective in suppressing blueberry mold growth [25]. It has also been reported that grape (cv. Isabella) volatiles reduce B. cinerea activity and inoculum density, thereby limiting incidence and infection in kiwifruits [8]. 


\subsection{Effect of Essential Oils on Fungal Diseases In Vivo}

Essential oils from a number of plants have shown activity against strawberry pathogens. For example, eucalyptus (Eucalyptus globulus L.) and cinnamon oil (C. zeylanicum, Blume) improved fruit quality and reduced fruit decay [12], while cinnamon bark EO reduced both C. acutatum and B. cinerea penetration, development and number of infected fruits at concentrations above $76.5 \mu \mathrm{L}$ $\mathrm{L}^{-1}$ of air [2]. Thyme (T. vulgaris L.) EO had higher antifungal activity and suppressed pathogen development at concentrations above $15.3 \mu \mathrm{L} \mathrm{L}^{-1}$ of air. At a higher concentration (153 $\mu \mathrm{L} \mathrm{L}^{-1}$ of air), thyme EO inhibited C. acutatum development on inoculated fruits [2]. Also, strawberry decay caused by $R$. stolonifer and B. cinerea was controlled by volatiles of T. vulgaris $[6,28]$ with both reports showing differences between thyme genotypes in terms of chemistry and efficacy.

Essential oils have also been tested on grape diseases. In a laboratory study, Walter et al. [26] found that EOs from clove (S. aromaticum (L.) Merr. E L.M. Perry), thyme, and massoialactone (derived from the bark of the tree Cryptocarya massoia R.Br.) significantly reduced necrotic lesions on grape leaves caused by B. cinerea when treated with thyme, and massoialactone. In a separate study, Valero et al. [27] showed that thymol or eugenol (volatile from clove) reduced the loss of sensory quality and microbial spoilage of grape in modified atmosphere storage.

Chitosan packages infused with $O$. vulgare essential oil changed spore and mycelia morphology and inhibited growth of $A$. niger, and R. stolonifer spore germination on inoculated grapes in storage [22]. The oils of $Z$. officinale, $O$. sanctum and P. persica were also effective in controlling storage rot of grapes during in vivo trials, with treated grapes showing an improved shelf life for up to 6 days [4].

\subsection{Effect of Volatiles and Essential Oils on Fruit Quality}

Wang et al. [16] found that treatment with thymol and eugenol extended strawberry shelf life and increased fruit free radical scavenging capacity, thereby enhancing resistance to spoilage and deterioration. Essential oil treated fruits were found to have higher amounts of sugars, flavonoids, anthocyanins, organic acid and phenolic compounds. The increase in phenolic content may have led to increased oxygen radical absorbance capacity (ORAC) and decreased fruit spoilage in essential oil treated strawberries [16].

Carvacrol, anethole, and perillaldehyde also enhanced antioxidant activity and increased total anthocyanins, phenolics and hydroxyl radical $(\bullet \mathrm{OH})$ scavenging capacity in blueberry fruit tissues [25]. Chitosan coating with carvacrol and cinnamaldehyde was also found to maintain blueberry firmness and effectively extended blueberry shelf life [30].

Similarly, postharvest essential oil treatments (perillaldehyde, linalool, cinnamaldehyde, cinnamic acid, anethole, and carvacrol) enhanced antioxidant capacity in raspberries with perillaldehyde being the most effective [29].

Grape berries in a modified atmosphere package with eugenol or thymol had lower weight loss, lower changes in skin color, reduced ripening, and lower decay throughout storage [27]. Lower weight loss was also seen in gerbera (Gerbera jamesonii cv. Dune) flowers treated with thymol [45].

Sánchez-González et al. [17] tested chitosan-coated packages of grapes alone or in mixture with bergamot essential oil and found chitosan mixed with bergamot oil to be the most effective to control respiration rate, water loss and antimicrobial activity during storage. Chitosan packages infused with O. vulgare essential oil also preserved the quality, physical, physiochemical and sensory attributes of grapes in storage [22].

\subsection{Mechanism of Fruit Resistance to Fungal Attack Treated by Volatiles and Essential Oils}

Plant volatiles play a major role in self-defense. Pe'rez et al. [46] observed that a $25 \%$ decrease in (E)-hex-2-enal content during strawberry development and ripening coincides with activation of latent infection, and appearance of visible disease symptoms, leading to extensive fruit damage. 
Six and nine-carbon volatiles are produced in plant tissues in response to wounding in LOX (liposygenase) and HPL (hydroperoxide lyase) pathways. In addition to their role in aroma biosynthesis, products of LOX and HPL pathways, have antimicrobial and antifungal activities and may have a role in plant-pathogen interactions. Some have also shown a stimulatory effect on some pathogenic fungi. In Arabidopsis thaliana, (E)-hex-2-enal activated several self-defense genes (i.e., lipoxygenase 2 and allene oxide synthase), lignified leaves and accumulated pathogenesis-related proteins (i.e., 3 transcripts, and camalexin), which reveals that volatile treatments stimulate a wound-repair mechanism, and will ultimately act as a physical barrier to the pathogen penetration [47]. Externally applied essential oils improved fruit resistance to fungal attack, mostly due to increased antiproliferative activity and free radical scavenging capacity in strawberries [16]. This has also been reported in kiwifruit (Actinidia deliciosa cv. 'Hayward') against B. cinerea with the application of grape (cv. Isabella) volatiles which induced mechanisms of resistance in the host [8].

Since plant volatiles inhibit fungal growth and are produced rapidly through the lipoxygenase pathway (in response to wounding), more studies are needed to further clarify their role in plant self-defense systems.

In addition to self-defense and induced resistance, essential oils affect pathogens by contact either in media or as volatiles in storage. Essential oils also lead to the secretion of cell protoplasts without previous cell wall disruption, as shown by the presence of chlamydospores and deformation of cell walls in B. cinerea hyphae treated with grape (cv. Isabella) volatiles [8].

The bioactivity of essential oils in the vapor phase is a very attractive characteristic that makes them suitable for use as fumigants in small fruits not suited to aqueous sanitation [16]. Easy application of essential oil vapors during storage makes them more attractive than dipping [48]. Essential oil application could also limit the spread of pathogens by suppressing spore production or reducing spore load on surfaces or in storage. However, the role of volatiles in spore germination and pathogen infectivity needs to be understood in order to develop new techniques for disease control [8].

\subsection{Phytotoxicity, Off-Flavor and Off-Odor of Volatiles and Essential Oils on Fresh Produce}

Extended exposure to volatiles has resulted in phytotoxicity on strawberry fruits and affected fruit quality [9]. The phytotoxicity of (E)-hex-2-enal has also been described on pears [49], beans [50], and sliced apples [51]. Volatiles 2-nonanone, hexan-1-ol and benzaldehyde slightly damaged strawberry fruit while (Z)-hex-3-en-1-ol and (E)-hex-2-enal caused extensive tissue necrosis [20]. Fallik et al. [52] reported strawberry weight loss and other side effects by (E)-hex-2-enal. Walter et al. [26] reported excessive water loss from detached grape branches (in the laboratory, but not in the field) exposed to thyme and massoialactone, and phytotoxicity on grape flowers in the field. Also, incorporation of bergamot essential oil in chitosan coating resulted in brown-colored grapes during storage [17].

In the authors' preliminary experiments with the application of thymol and carvacrol in air-tight containers, phytotoxicity was observed as increased mushiness and dullness of strawberry fruits after 24 hours (unpublished data). However, Bhaskara Reddy et al. [6] did not observe any visual phytotoxic symptoms after 4 days of fruit exposure to T. vulgaris essential oils. Further work is needed to identify and minimize the cause of adverse effects on fruit quality by volatiles [9].

Very few studies have reported on the sensory characteristics of fruits treated with essential oils. Neri et al. [47] reported off-odors in peach and nectarine fruits treated with (E)-hex-2-enal described as a "green" (leafy) and "butyric" aroma. However, off-odors decreased during ripening and nothing was perceived after ripening. No fruit off-odors were observed in peach and nectarine fruits treated with carvacrol or citral. Aloui et al. [53] reported complete absence of off-flavors and off-odors in dates treated with citrus essential oils. Serrano et al. [54] treated cherries with eugenol, thymol or menthol and reported no sensory effects. However, cherries treated with eucalyptol generated off-flavors. Prasad \& Stadelbacher [55], reported that acetaldehyde treated strawberries did not show any off-flavor at a concentration of $1 \%$, but showed off-flavor at $4 \%$. 
The reviewed articles suggest that most of the essential oils do not leave off-flavors or off-odors on intact fruits at the minimum inhibitory concentrations, especially when stored fruits finish their ripening process. However, there is variation between fruit species and cultivars and each commodity has to be tested individually. For example, Neri et al. [47], reported that stone fruits were more sensitive to (E)-hex-2-enal injury than pome fruits and showed off-flavor, probably because they absorb more (E)-hex-2-enal than pome fruits.

\section{Control of Fungal Diseases in the Field}

To our knowledge, only one research paper described the application of essential oils in the field. A single application of thyme oil or massoialactone application on grape bunches and leaves reduced B. cinerea in the field trial [26]. However, the efficacy of Thyme oil to control bunch rot needs further field evaluations, as floral tissue browning occurred [26].

\section{Conclusions}

In this review, the efficacy of essential oils (plant-based multi-compounds) and single compound volatiles was discussed in in vitro, in vivo (in storage) and in situ (in the field) conditions. Despite the importance of fresh fruits food safety, there are not many research articles on the effectiveness of essential oils to control bacteria populations on small fruits, which suggests the need for research in this area. Many research articles discussed the positive effects of volatiles and essential oils in in vitro conditions on media-grown fungal populations with a large variation in their efficacy and their minimum inhibitory concentrations. Most of these variations were related to the vapor pressure of volatiles.

The efficacy of multi-compound essential oils is even more variable due to genetic variation, environmental conditions, and synergistic effects of multiple compounds. Major compounds play an essential role in the antimicrobial activity of essential oils, however, minor compounds in the mixture may have synergistic effects. Future studies are needed to explain the role of single natural compounds or their combination in plant-fungal interactions.

(E)-hex-2-enal and hexanal were the most effective volatiles and thyme the most effective essential oil in controlling fungal diseases of small fruits both in vitro and in storage. Thyme oil has the potential as a postharvest treatment to extend shelf life of fresh fruits and vegetable and to replace commercial fungicides or controlled atmosphere storage. However, active packaging and improved formulation techniques are needed to prolong activity, reduce volatility and improve coverage.

Several researchers have mentioned the toxicity of volatiles and essential oils after extended exposure. Research is needed to study the effect of volatiles and essential oils on vegetative and reproductive phases of fungal development, fruit quality (firmness, sensory evaluations), cell wall structure and integrity and their role in plant self-defense and postharvest storage.

Acknowledgments: We would like to thank our colleague, Laban Rutto for the critical review of this manuscript. This article is a contribution of the Virginia State University (VSU), Agricultural Research Station (Journal Article Series Number 353).

\section{References}

1. Centers for Disease Control and Prevention (CDC), National Outbreak Reporting System (NORS). Available online: https: / / wwwn.cdc.gov/norsdashboard/ (accessed on 4 June 2018).

2. Duduk, N.; Markovic, T.; Vasic, M.; Duduk, B.; Vico, I.; Obradovic, A. Antifungal Activity of Three Essential Oils against Colletotrichum acutatum, the Causal Agent of Strawberry Anthracnose. J. Essent. Oil Bear. Plant. 2015, 18, 529-537. [CrossRef]

3. Agrios, G.N. Significance of plant diseases; Plant pathology; Academic Press: London, UK, 2000; pp. $25-37$.

4. Tripathi, P.; Dubey, N.K.; Shukla, A.K. Use of some essential oils as post-harvest botanical fungicides in the management of grey mold of grapes caused by Botrytis cinereal. World J. Microbiol. Biotechnol. 2008, 24, 39-46. [CrossRef] 
5. Perdones, A.; Sánchez-Gonzáleza, L.; Chiralt, A.; Vargas, M. Effect of chitosan-lemon essential oil coatings on storage-keeping quality of strawberry. Postharvest Biol. Technol. 2012, 70, 32-41. [CrossRef]

6. Bhaskara Reddy, M.V.; Angers, P.; Gosselin, A.; Arul, J. Characterization and use of essential oil from Thymus vulgaris against Botrytis cinerea and Rhizopus stolonifer in strawberry fruits. Phytochemistry 1998, 47, 1515-1520. [CrossRef]

7. Daferera, D.J.; Ziogas, B.N.; Polissiou, M.G. The effectiveness of plant essential oils on the growth of Botrytis cinerea, Fusarium sp., and Clavibacter michiganeneis subs. Michiganensis. Crop Prot. 2003, 22, 39-44. [CrossRef]

8. Kulakiotu, E.K.; Thanassoulopoulos, C.C.; Sfakiotakis, E.M. Postharvest biological control of Botrytis cinerea on kiwifruit by volatiles of 'Isabella' grapes. Phytopathology 2004, 94, 1280-1285. [CrossRef] [PubMed]

9. Arroyo, F.T.; Moreno, J.; Daza, P.; Boianova, L.; Romero, F. Antifungal activity of strawberry fruit volatile compounds against Colletotrichum acutatum. J. Agric. Food Chem. 2007, 55, 5701-5707. [CrossRef] [PubMed]

10. Environmental Working Group (EWG). Dirty Dozen list. Available online: https://www.ewg.org/ foodnews / dirty_dozen_list.php (accessed on 9 March 2018).

11. Research Council; Board of Agriculture. Regulating Pesticides in Food-The Delaney Paradox; National Academy Press: Washington, DC, USA, 1987.

12. Tzortzakis, N.G. Maintaining postharvest quality of fresh produce with volatile compounds. Innov. Food Sci. Emerg. Technol. 2007, 8, 111-116. [CrossRef]

13. Tzortzakis, N.G.; Economakis, C.D. Antifungal activity of lemongrass (Cympopogon citratus L.) essential oil against key postharvest pathogens. Innov. Food Sci. Emerg. Technol. 2007, 8, 253-258. [CrossRef]

14. Almenar, E.; Auras, R.; Rubino, M.; Harte, B. A new technique to prevent the main post harvest diseases in berries during storage: Inclusion complexes $\beta$-cyclodextrin-hexanal. Int. J. Food Microbiol. 2007, 118, 164-172. [CrossRef] [PubMed]

15. Hamilton-Kemp, T.R.; Archbold, D.D.; Loughrin, J.H.; Andersen, R.A.; McCracken, C.T.; Collins, R.W. Stimulation and inhibition of fungal pathogens of plants by natural volatile phytochemicals and their analogs. Curr. Top. Phytochem. 2000, 4, 95-104.

16. Wang, C.Y.; Wang, S.Y.; Yin, J.J.; Parry, J.; Yu, L.L. Enhancing Antioxidant, Antiproliferation, and free radical scavenging activities in strawberries with essential oils. J. Agric. Food Chem. 2007, 55, 6527-6532. [CrossRef] [PubMed]

17. Sánchez-González, L.; Pastor, C.; Vargas, M.; Chiralt, A.; González-Martínez, C.; Cháfer, M. Effect of hydroxypropylmethylcellulose and chitosan coatings with and without bergamot essential oil on quality and safety of cold-stored grapes. Postharvest Biol. Technol. 2011, 60, 57-63. [CrossRef]

18. Wilson, C.L.; Solar, J.M.; El Ghaouth, A.; Wisniewski, M.E. Rapid evaluation of plant extracts and essential oils for antifungal activity against Botrytis cinerea. Plant Dis. 1997, 81, 204-210. [CrossRef]

19. Hamilton-Kemp, T.R.; Mccracken, C.T.; Loughrin, J.H.; Andersen, R.A.; Hildebrand, D.F. Effects of some natural volatile compounds on the pathogenic fungi A. alternata and Botrytis cinereal. J. Chem. Ecol. 1992, 18, 1083-1091. [CrossRef] [PubMed]

20. Vaughn, S.F.; Spencer, G.F.; Shasha, B.S. Volatile compounds from raspberry and strawberry fruit inhibit postharvest decay fungi. J. Food Sci. 1993, 58, 793-796. [CrossRef]

21. Combrinck, S.; Regniera, T.; Kamatoub, G.P.P. In vitro activity of eighteen essential oils and some major components against common postharvest fungal pathogens of fruit. Ind. Crop. Prod. 2011, 33, 344-349. [CrossRef]

22. Santos, N.S.T.; Aguiar, A.J.A.A.; de Oliveira, C.E.V.; de Sales, C.V.; Silva, S.M.; Silva, R.S.; Stamford, T.C.M.; de Souza, E.L. Efficacy of the application of a coating composed of chitosan and Origanum vulgare L. essential oil to control Rhizopus stolonifer and Aspergillus niger in grapes (Vitis labrusca L.). Food Microbiol. 2012, 32, 345-353. [CrossRef] [PubMed]

23. Bouchra, C.; Achouri, M.; Hassani, L.M.I.; Hmamouchi, M. Chemical composition and antifungal activity of essential oils of seven Moroccan Labiate against Botrytis cinerea Pers: Fr. J. Ethnopharmacol. 2003, 89, 165-169. [CrossRef]

24. Archbold, D.D.; Hamilton-Kemp, T.R.; Barth, M.M.; Langlois, B.E. Identifying Natural Volatile Compounds That Control Gray Mold (Botrytis cinerea) during Postharvest Storage of Strawberry, Blackberry, and Grape. J. Agric. Food Chem. 1997, 45, 4032-4037. [CrossRef]

25. Wang, C.Y.; Wang, S.Y.; Chen, C. Increasing antioxidant activity and reducing decay of blueberries by essential oils. J. Agric. Food. Chem. 2008, 56, 3587-3592. [CrossRef] [PubMed] 
26. Walter, M.; Jaspers, M.V.; Eade, K.; Frampton, C.M.; Stewart, A. Control of Botrytis cinerea in grape using thyme oil. Australas. Plant Pathol. 2001, 30, 21-25.

27. Valero, D.; Valverde, J.M.; Martı́nez-Romero, D.; Guille'n, F.; Castillo, S.; Serrano, M. The combination of modified atmosphere packaging with eugenol or thymol to maintain quality, safety and functional properties of table grapes. Postharvest Biol. Technol. 2006, 41, 317-327. [CrossRef]

28. Nabigol, A.; Morshedi, H. Evaluation of the antifungal activity of the Iranian thyme essential oils on the postharvest pathogens of strawberry fruits. Afr. J. Biotechnol. 2011, 10, 9864-9869.

29. Jin, P.; Wang, S.Y.; Gao, H.; Chen, H.; Zheng, Y.; Wang, C.Y. Effect of cultural system and essential oil treatment on antioxidant capacity in raspberries. Food Chem. 2012, 132, 399-405. [CrossRef] [PubMed]

30. Sun, X.; Narciso, J.; Wang, Z.; Ference, C.; Bai, J.; Zhou, K. Effects of Chitosan-Essential Oil Coatings on Safety and Quality of Fresh Blueberries. J. Food Sci. 2014, 79, 955-960. [CrossRef] [PubMed]

31. Calo, J.R.; Crandall, P.G.; Bryan, C.O.; Ricke, S. Essential oils as antimicrobials in food systems-A review. Food Control. 2015, 54. [CrossRef]

32. Andersen, R.A.; Hamilton-Kemp, T.R.; Hildebrand, D.F.; McCracken, C.T., Jr.; Collins, R.W.; Fleming, P.D. Structure-antifungal activity relationships among volatile C6 and C9 aliphatic aldehydes, ketones, and alcohols. J. Agric. Food. Chem. 1994, 42, 1563-1568. [CrossRef]

33. Song, J.; Leepipattanawit, R.; Deng, W.; Beaudry, R.M. Hexanal vapor is a natural metabolizable fungicide: Inhibition of fungal activity and enhancement of aroma biosynthesis in apple slices. J. Am. Soc. Hortic. Sci. 1996, 121, 937-942.

34. Bakkali, F.; Averbeck, S.; Averbeck, D.; Idaomar, M. Biological effects of essential oils-A review. Food Chem. Taxicol. 2008, 46, 446-475. [CrossRef] [PubMed]

35. Caccioni, D.R.L.; Gardini, F.; Lanciotti, R.; Guerzoni, M.E. Antifungal activity of natural volatile compounds in relation to their vapor pressure. Sci. Aliments 1997, 17, 21-34.

36. Monzote, L.; Stamberg, W.; Staniek, K.; Gille, L. Toxic effects of carvacrol, caryophyllene oxide, and ascaridole from essential oil of Chenopodium ambrosioides on mitochondria. Toxicol. Appl. Pharmacol. 2009, 240, 337-347. [CrossRef] [PubMed]

37. Gardini, F.; Lanciotti, R.; Caccioni, D.R.L.; Guerzoni, M.E. Antifungal activity of hexanal as dependent on its vapor pressure. J. Agric. Food Chem. 1997, 33, 50-55. [CrossRef]

38. Inouye, S.; Takizawa, T.; Yamaguchi, H. Antibacterial activity of essential oils and their major constituents against respiratory tract pathogens by gaseous contact. J. Antimicrob. Chemother. 2001, 47, 565-573. [CrossRef] [PubMed]

39. Chavan, P.S.; Tupe, S.G. Antifungal activity and mechanism of action of carvacrol and thymol against vineyard and wine spoilage yeasts. Food Control 2014, 46, 115-120. [CrossRef]

40. Sivakumar, P.M.; Kumar, T.M.; Doble, M. Antifungal activity, mechanism and QSAR studies on chalcones. Chem. Biol. Drug Des. 2009, 74, 68-79. [CrossRef] [PubMed]

41. Rozmer, Z.; Perjési, P. Naturally occurring chalcones and their biological activities. Phytochem. Rev. 2016, 15, 87-120. [CrossRef]

42. Kurita, N.; Miyaji, M.; Kurane, R.; Takahara, Y.; Ichimura, K. Antifungal activity and molecular orbital energies of aldehyde compounds from oils of higher plants. Agric. Biol. Chem. 1979, 43, 2365-2371.

43. Babu, K.S.; Li, X.C.; Jacob, M.R.; Zhang, Q.; Khan, S.; Ferreia, D.; Clark, A.M. Synthesis, antifungal activity, and structure-activity relationships of coruscanone A. analogs. J. Med. Chem. 2006, 49, 7877-7886. [CrossRef] [PubMed]

44. Wedge, D.E.; Galindo, J.C.G.; Macias, F.A. Fungicidal activity of natural and synthetic sesquiterpene lactone analogs. Phytochemistry 2000, 53, 747-757. [CrossRef]

45. Solgi, M.; Kafi, M.; Taghavi, T.S.; Naderi, R. Essential oils and silver nanoparticles (SNP) as novel agents to extend vase-life of gerbera (Gerbera jamesonii cv. ‘Dune') flowers. Postharvest Biol. Technol. 2009, 53, 155-158. [CrossRef]

46. Pe'rez, A.G.; Sanz, C.; Olias, R.; Olias, J.M. Lipoxygenase and hydroperoxide lyase activities in ripening strawberry fruits. J. Agric. Food Chem. 1999, 47, 249-253. [CrossRef]

47. Neri, F.; Mari, M.; Brigati, S.; Bertolini, P. Fungicidal activity of plant volatile compounds for controlling Monilinia laxa in stone fruit. Plant Dis. 2007, 91, 30-35. [CrossRef]

48. Jobling, J. Essential oils: A new idea for postharvest disease control. Good Fruit and Vegetables Magazine 2000, 11, 50. Available online: http://www.postharvest.com.au/gfv_oils.pdf (accessed on 3 October 2018). 
49. Neri, F.; Mari, M.; Brigati, S. Control de Penicillium expansum by plant volatile compounds. Plant Pathol. 2006, 55, 100-105. [CrossRef]

50. Croft, K.P.C.; Juttner, F.; Slusarenko, A.J. Volatile products of the lipoxygenase pathway evolved from Phaseolus Vulgaris (L.) leaves inoculated with Pseudomonas syringae pV phaseolicola. Plant Physiol. 1993, 101, 13-24. [CrossRef] [PubMed]

51. Corbo, M.R.; Lanciotti, R.; Gardini, F.; Sinigaglia, M.; Guerzoni, M.E. Effects of hexanal, trans-2-hexenal and storage temperature on shelf life of fresh sliced apples. J. Agric. Food Chem. 2000, 48, 2401-2408. [CrossRef] [PubMed]

52. Fallik, E.; Archbold, D.D.; Hamilton-Kemp, T.R.; Clements, A.M.; Collins, R.W.; Barth, M.M. (E)-2-Hexenal both stimulates and inhibits Botrytis cinerea growth in vitro and on strawberry fruit in vivo. J. Am. Soc. Hortic. Sci. 1998, 123, 875-881.

53. Aloui, H.; Khwaldia, K.; Licciardello, F.; Mazzaglia, A.; Muratore, G.; Hamdi, M.; Restucciad, C. Efficacy of the combined application of chitosan and Locust Bean Gum with different citrus essential oils to control postharvest spoilage caused by Aspergillus flavus in dates. Int. J. Food Microbiol. 2014, 170, 21-28. [CrossRef] [PubMed]

54. Serrano, M.; Martinez-Romero, D.; Castillo, S.; Guille, F.; Valero, D. The use of natural antifungal compounds improves the beneficial effect of MAP in sweet cherry storage. Innov. Food Sci. Emerg. Technol. 2005, 6, 115-123. [CrossRef]

55. Prasad, K.; Stadelbacher, G.J. Effect of acetaldehyde vapor on postharvest decay and market quality of fresh strawberries. Phytopathology 1974, 64, 948-951. [CrossRef]

(C) 2018 by the authors. Licensee MDPI, Basel, Switzerland. This article is an open access article distributed under the terms and conditions of the Creative Commons Attribution (CC BY) license (http:/ / creativecommons.org/licenses/by/4.0/). 